\title{
特集＼cjkstart高齡者手術成績向上における工夫 1
}

\section{0歳以上の高齢者に対する膵頭十二指腸切除術の検討 一早期退院に向けて一}

\begin{tabular}{|c|c|c|c|c|}
\hline \multicolumn{5}{|c|}{ 飯塚病院外科 } \\
\hline 梶山 & 播本 & 憲史 & 永田 茂行 & 平山 佳愛 \\
\hline 中ノ子智徳 & 由茅 & 隆文 & 吉田倫太郎 & 西田康二郎 \\
\hline 占賀 聡 & 甲斐 & 正徳 & & \\
\hline
\end{tabular}

\section{内容要旨}

目的：80歳以上の高齢者に対する膵頭十二指腸切除術（Pancreaticoduodenectomy；PD）の早期退 院に関与する因子を検討した，対象・方法：PDを施行した80歳以上の高齢者 12 例に対し，年齢，性， 診断, 手術術式, 膵消化管再建法, 膵管ドレナージ法, 手術時間, 出血量, PD経験豊富な外科医の関 与, 膵液瘦, 胃内容排泄遅延, 創感染, 術前併存症, 術後合併症, 経腸 (経管) 栄養などの有無, 術 後在院日数, 在院死亡を解析した. また術後 30 日以内に退院した短期入院群と術後31日以降に退院し た長期入院群に分け, 比較検討した。結果 : 早期退院群では, PD経験豊富な外科医の関与が有意に多 く, Grade B/Cの膵液瘦が有意に少なかった．膵管ドレナージ法では, 膵管ロストステントの有用性 が示唆された。結語：80歳以上の高齢者に対するPDにおいては, PD経験豊富な外科医の関与が術後 膵液瘦を減少させ，結果的に早期退院に寄与する可能性があると思われた.

索引用語：膵頭十二指腸切除術, 高齢者, 80歳以上, 外科医の経験, 早期退院

\section{はじめに}

膵頭十二指腸切除術 (Pancreaticoduodenectomy；PD）は高度の侵襲を伴う手術であるが，高 齢化社会に伴い高齢者でPDを必要とする症例は 増加している。高齢者のPDでは, 縫合不全をはじ め小さな術後合併症でも, それが誘因となって致 死的になることもある. PDの術後死亡率は, 80 歳 以上では $4.1 \%, 80$ 歳未満では $1.7 \%$ と報告されてい る ${ }^{1)}$. また, 術後在院死亡に至らなくても, 長期入 院になると, とくに80歳以上の高齢者ではactivity of daily living (ADL) の低下も著しい. 術後いか に早期に退院させるかは, 患者のその後のquality

第37回日本外科系連合学会学術集会パネルディスカ ッション 9

連絡先 梶山 潔

T 820-8505 福岡県飯塚市芳雄町 3-83 飯塚病院外科 of life (QOL) にも大きく影響すると思われる．今 回, 当科における80歳以上のPD症例を臨床的に解 析し, とくに早期退院に関与する因子を検討した.

\section{対象と方法}

2002 年 1 月より 2011 年 12 月までの 10 年間に, 当 科で施行されたPD159例中80歳以上の症例 12 例を 対象とした。

1. 12例について, 次の臨床事項を検討した. 年齢, 性, 診断, 術前併存症, 手術術式, 膵消化 管再建法 (膵腸吻合または胃膵吻合), 膵管ドレナ ージ法 (外瘦または内瘦), 手術時間, 出血量, PD 経験豊富な外科医の関与（術者または第一助手と して100例以上の経験; Surgeon A，100例未満の 経験; Surgeon B), 膵液瘦 (International study group of pancreatic fistula ; ISGPF分類 ${ }^{2}$ に従っ た), 胃内容排泄遅延 (Delayed gastric emptying; DGE), 創感染, 術後合併症, 経腸 (経管) 栄養 などの有無, 術後在院日数, 在院死亡. 
2. 12 例を術後 30 日以内に退院した短期入院群 （A群；6例）と術後31日以降に退院した長期入 院群（B群； 6 例）の 2 群に分け，早期退院に関 与する因子を検討した.

なお，統計解析にはStatView 日本語版 version 5 (SAS社, 米国) を使用し， $\chi^{2}$ 両側検定お よびMann-Whitney U検定を行い, $p$ 值 $<0.05$ を有 意差ありとした。

\section{結 果}

1. PD159例中80歳以上の症例は12例で, 全体 の7.5\%であった. 12 例の平均年齢は $83.0 \pm 2.6$ 歳

(80 89歳), 男性は 2 例, 女性は 10 例. 診断は十 二指腸乳頭部癌 3 例, 胆管癌 5 例, 膵頭部癌 4 例. 術前併存症は高血圧症, 胃潰瘍, 不整脈, 慢 性心不全，気管支喘息などで，10例（83.3\%）と 高率であった. 手術術式はPDが 4 例でいずれも脺 腸吻合, 亜全胃温存膵頭十二指腸切除術 (Subtotal stomach preserving PD ; SSPPD) が 8 例, 膵腸 吻合が 6 例，胃膵吻合が 2 例であった。膵管ドレ ナージの方法は節付き膵管チューブを用いた外瘻 が 5 例， ロストステント（8 Fr栄養チューブの先 端 $4 \mathrm{~cm}$ を切断して使用）を用いた内瘦が 6 例, ス テントなしが 1 例. 平均手術時間は $486.7 \pm 60.0$ 分, 平均出血量は $1,094.5 \pm 689.2 \mathrm{ml}$. 術後膵液瘦は ISGPF分類による膵液㾇なし 2 例, Grade A 5 例, Grade B 5 例, Grade C 0 例. 術後在院日数 は平均39.1 \pm 21.8 日（14～76日）, 在院死亡はなか った。詳細をTable 1 とTable 2 に示す.

2. A 群とB群を比較すると, 年齢, 性, 診断, 術前併存症, 手術術式, 膵消化管再建法, 手術時 間, 出血量, DGE, 創感染, 術後合併症, 経腸栄 養などの有無に有意差はなかった。両群とも在院 死亡はなかった，A群ではB群に比べ，PD経験豊 富な外科医の関与が有意に多く $(p<0.01)$, ISGPF Grade B/Cの膵液瘦が有意に少なかった $(p<0.01)$ ．また, 膵管ドレナージ法では, 膵管チ ユーブによる外瘻よりも膵管ロストステントによ る内瘦が多い傾向であった（Table 3 ).

\section{考察}

わが国では急速な人口の高齢化が進み, 総務省 統計局のデータによると, 平成21年時点で65歳以 上の高齢者の総人口に占める割合は $22.7 \%$ であ

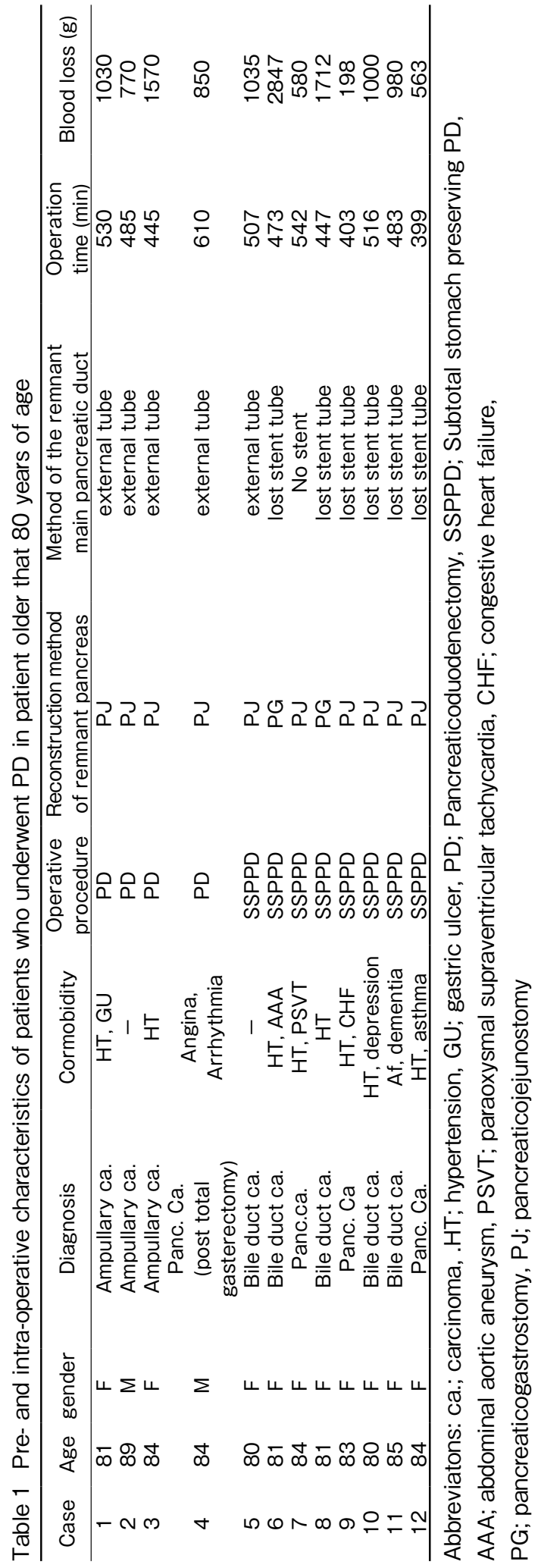


日本外科系連合学会誌 第 38 巻 1 号

Table 2 Post-operative characteristics of patients who underwent PD in patient older that 80 years of age

\begin{tabular}{|c|c|c|c|c|c|c|c|c|}
\hline Case & Surgeon & PF & DGE & SSI & $\begin{array}{l}\text { Postoperative } \\
\text { complications }\end{array}$ & Enteral nutrition & $\begin{array}{c}\text { Postoperative } \\
\text { hospital stay (days) }\end{array}$ & Mortality \\
\hline 1 & B & B & + & - & neurogenic bladder, UTI & + & 76 & - \\
\hline 2 & B & A & - & + & MRSA colitis & + & 54 & - \\
\hline 3 & B & B & - & + & MRSA pneumonia & + & 70 & - \\
\hline 4 & B & B & - & + & - & + & 48 & - \\
\hline 5 & B & A & - & - & - & + & 26 & - \\
\hline 6 & A & A & - & + & pleural effusion, delirium & + & 16 & - \\
\hline 7 & A & No & - & + & PSVT & + & 22 & - \\
\hline 8 & A & A & + & - & - & - & 19 & - \\
\hline 9 & A & No & - & - & DVT & + & 23 & - \\
\hline 10 & B & B & - & + & $\begin{array}{l}\text { depression, } \\
\text { pulmonary edema }\end{array}$ & + & 56 & - \\
\hline 11 & B & B & - & + & Af & + & 45 & - \\
\hline 12 & A & A & - & - & $\begin{array}{c}\mathrm{Af}, \\
\text { Obstruction of lost stent }\end{array}$ & + & 14 & - \\
\hline
\end{tabular}

Abbreviatons: PF; pancreatic fistula, DGE; delayed gastric emptying, UTI; urinary tract infection,

PSVT; paraoxysmal supraventricular tachycardia, DVT; deep vein thrombosis,

Surgeon A: Surgeon who experienced more than 100 PDs

Surgeon A: Surgeon who experienced less than 100 PDs

Table 3 Factors for early dischage

\begin{tabular}{lccc}
\hline & $\begin{array}{c}\text { Short hospital stay } \\
(\mathrm{n}=6)\end{array}$ & $\begin{array}{c}\text { Long hospital stay } \\
(\mathrm{n}=6)\end{array}$ & $p$ \\
\hline Gender (M/F) & $2 / 6$ & $0 / 6$ & $\mathrm{NS}$ \\
Age (yrs, mean) & 82.1 & 83.8 & NS \\
Comorbidity & 5 & 5 & NS \\
Operative time (min) & 461.8 & 511.5 & $\mathrm{NS}$ \\
blood loss (g) & 1155.8 & 1028.8 & 0.07 \\
Reconstrucion using lost stent & 5 & 2 & $0.01>$ \\
Particpation of experienced surgeon & 5 & 0 & $0.01>$ \\
Pancreatic fistula (ISGPF Grade B/C) & & 5 & NS \\
DGE & 0 & & NS \\
SSI & 1 & 5 & NS \\
Postoperative complication & 3 & 5 & \\
\hline
\end{tabular}

Abbreviatons: DGE; delayed gastric emptying, SSI; surgical site infection

り, 80歳以上の割合は $6.2 \%$ と報告されている ${ }^{3)}$.今 後, その割合はさらに増加すると推定されている. 一方で, 手術手技の安定化, 周術期管理や麻酔技 術の進歩により高齢者に対する手術の安全性も向 上し，80歳以上の高齢者に対しても積極的に手術 が行われるようになってきた。しかし，80歳以上 の高齢者では各臓器の予備能が低下していること がよく知られており，とくに循環器系疾患や呼吸 器系疾患の割合が多いとされている ${ }^{4) 5}$. 超高齢者 に対する高度侵襲手術の適応について, 水野ら ${ }^{6)}$ は, (1)Performance status (PS) がGrade 0 もしく は $1, \mathrm{ADL}$ が良好で身体的自立ができていること， (2)心・肺・肝・腎などの重要臟器に大きな障害が なく, 耐術可能であること, (3)Curability B以上の
手術が可能であること, (4)家族が術後の患者の予 想されうる状況を理解し受容可能であることとし ている. 加えて, 鈴村ら ${ }^{7}$ は, 当然ながら本人が手 術治療を希望していることが重要と述べている.

PDは消化器外科領域の手術の中で最も侵襲の 大きな手術の一つで，また技術的にも高難易度と されている. 高齢者に対するPDについては様々な 報告がある. 福島ら ${ }^{8}$ は, 80歳以上の高齢者では術 前併存疾患や術後合併症が80歳未満の症例に比べ 多いが, 術前からの十分な対応に加え, 術中・術 後合併症に対し根治性を損なわない範囲で手術侵 襲をできる限り小さくすること, 縫合不全などの 手術に起因した合併症を極力なくすことにより， 80歳以上の症例に対してもPDを施行できると述 
べている. 木下ら ${ }^{9}$ は, 70歳以上の高齢者に行った PD51例を解析し, (1)高齢者は複数の併存疾患を持 っていることが多く, 術前の十分なコントロール が必要, (2)術後合併症を起こしやすく, 容易に重 篤化するため, 合併症の発生が疑われれば早期に 積極的に対処する, (3)厳重な術前・術中・術後管 理を行えば比較的安全にPDを行えるが, 血管合併 切除や広範囲リンパ節郭清に関しては, 患者の QOLを考慮して行う，(4)患者自身およびその家族 が本当に治療を望んでいる場合にPDを行うべき と述べている．また杉本ら ${ }^{10)}$ は，80歳以上の高齢 者はAmerican society of anesthesiologists (ASA) Scoreが高值であり, 腎・肺機能が低く, すべての 合併症が80未満の症例に比べて多く, とくにせん 妄と創感染の合併率が有意に高く, 膵液癭ISGPF Grade B/Cも多い傾向にあったとし, 感染症対策, 栄養管理, 精神状態の管理を包括的に行うことが 重要と述べている.

われわれの症例では, 幸い在院死亡はなかった が, 今まで80歳以上の患者に対して具体的なPD適 応の条件を定めていたわけではない.80歳以上の 患者に対しては, 各担当医が外来診察の時点から PSの良い症例, 各検査所見の良好な症例, 併存疾 患が重篤でない症例を手術適応とし, 併存疾患が 多くPSが悪い症例は適応外とされた可能性があ る、つまり，自然に患者がセレクションされてい た可能性があると思われるが，前述のごとくとく に80歳以上の高齢者に対しては, 併存疾患やPSに より今後も慎重に手術適応を判断すべきと考えて いる.

今回は症例数も少なく後方視的検討であるが, あえて客観的評価が難しいPD経験豊富な外科医 の関与という観点からも検討してみた。現代のイ ンターネット社会では, 非医療関係者でも簡単に 詳細な医学知識を入手することができ，また患者 の権利意識も大幅に高くなっている. さらに, 社 会から医療現場に求められる診療レベルが非常に 高くなっていることも事実である。このような背 景もあって, 近年, わが国でも日本肝胆膵外科学 会高度技能専門医や日本内視鏡外科学会技術認定 など，学会が手術手技自体に重点を置いた専門医 や指導施設の制度が増加している. PDについてみ
ると, 北米メリーランド州で行われたPD症例の解 析では, 在院死亡率は症例数と強く相関し, 症例 数の少ない病院の死亡率は多い病院と比較し 8.7 倍と報告されている ${ }^{11)}$.ニューヨーク州では, 年 間症例数が多い施設ほど手術死亡率が低く在院日 数も短くなり，また膵切除執刀数が多い外科医ほ ど手術死亡率が低く, 平均在院日数の短かったと 述べられている ${ }^{12)}$. フィンランドでは, 病院の年 間のPD症例数が増えるに従い, また外科医の年間 手術症例数が増えるに従い在院死亡率は減少し, 限られた病院で経験を積んだ外科医が手術するこ とが重要との主張がある ${ }^{13)}$ 。このような報告をふ まえ, わが国では日本膵臓学会の「科学的根拠に 基づく膵癌診療ガイドライン 2009 年版」 ${ }^{14)}$ の中に, 推奨グレードBとしながらも,「膵頭十二指腸切除 術など膵癌に対する外科切除術では, 手術症例数 が一定以上ある専門医のいる施設では合併症が少 ない傾向であり，合併症発生後の管理も優れてい ると推察される」と述べられている。ささらに“明日 への提言”として,「PDは難易度の高い手術であ り, 術後合併症の頻度が高く, 重篤な合併症へと 発展する可能性があることを留意しなければなら ない，症例の多い施設では合併症の頻度も低く， 合併症が発生した際も適切な対応をとりやすい」 との記述がある. PDに限らずどのような手術でも 同様のことが言えるのは, 多くの外科医が実感し ていることであろう。

当科のPDでは, 時代的変遷が大きく影響してい ると思われる．検討した10年間のうち，2002年か らの前半 5 年間は術者にかなりのばらつきがあ り, 手術術式, 脺消化管再建法, 術後管理法も主 治医（執刀医）により異なる方法がとられ，さら に胆膵外科が専門でない外科医も執刀していた. 一方, 後半の 5 年間は胆脺外科を専門とし, PD経 験100例以上の経験豊富な外科医が関与すること となり, 手術術式, 手術手順, 術後管理も定まっ た方法で行うようになった。 そして問題が生じれ ば，その都度改善してきた。経験豊富な外科医の 関与とは, その外科医が直接執刀することで到達 度の高い手術手技を施行でき, 合併症予防に役立 つことは言うまでもない。 また, 実際に執刀しな くても指導的助手の役割を果たせば, 経験の少な 
い外科医の手術の精度を大幅に上げると思われ る. 術後管理では, 仮に合併症が発生した場合で も早期に適切な治療ができることで, 合併症を遷 延させないこと，致死的にならないことに大きく 貢献する．簡単に言えば, “PDに慣れている”“PD の奥深さを知っている”とも言えるのではないだ ろうか. 今回の検討では, PDの最大の合併症であ る膵液瘦が早期退院に関与していると思われた が,この膵液瘦と外科医の経験とは強く相関して いると思われる. Schmidtら ${ }^{15}$ は, 50例以上の執刀 経験のある外科医は50例未満の外科医に比へ，有 意に手術時間が短く, 出血量が少なく, 膵液瘦や 術後合併症の頻度が有意に低いと報告している。 Tseng ${ }^{16)}$ は, PDのlearning curveを検討し, 60 例を超えると出血量, 手術時間, 在院日数が有意 に減少すると述べている.

筆者自身はPD経験が150例に満たない状況であ るが，自分自身の歴史を振り返ってみても，初期 の頃は手術手技が不十分であったことは否めず， 経験（失敗）を重ねる度に修正・改善を行ってき た．その結果，合併症に対する対応策や次回の手 術で講じるべき合併症予防策のレベルも向上して きた．まだまだ発展途上ではあるが，多くの経験 の中から手術手技や周術期管理の総合力は積み上 げられてきたと考えている．外科の教科書やビデ オなど外科医が学習する機会は10数年前と比較し 格段に増えたが，やはり実際の手術室やべッドサ イドに優る教材はない. 今後も 1 例 1 例に真摰に 向き合い, 自らの手術技術と診療のレベル向上, チーム医療の充実, 若手外科医の育成に努めたい と考えている.

\section{結 語}

80歳以上の高齢者に対するPDにおいては, PD 経験豊富な外科医の関与が術後膵液瘦を減少さ せ, 結果的に早期退院へ寄与できる可能性がある と思われた。 また，膵管ロストステントなど，早 期に退院できる工夫も必要である.

\section{文献}

1) Makary MA, Winter JM, Yeo CJ, et al: Pancreaticoduodenectomy in the very elderly. J Gastrointest Surg 10:347-356, 2006
2) Bassi C, Dervenis C, Buchler M, et al: Postoperative pancreatic fistula: an international study group (ISGPF) definition. Surgery $138: 8-13,2005$

3）総務省：統計局ホームページ : http://www.stat. go.jp/data/topics/topi411.htm 平成24年10月 15 日参照

4）岩井和浩, 川崎亮輔, 妻鹿成治, 他：高齢者（85 歳以上) 腹部緊急手術症例の検討. 外科 68:819822, 2006

5）湊屋 剛, 西村元一, 安居利晃, 他 : 高齢者（75 歳以上）腹部緊急手術症例の検討. 日外系連会誌 24:761-764, 1999

6）水野憲治, 吉山知幸, 青木秀樹, 他：超高齢者の 膵管内乳頭粘液性膵癌 - 胆管癌・胃癌の 3 重複癌 の 1 例. 日臨外会誌 $65: 3344-3349,2004$

7）鈴村和大, 黒田暢一, 飯室勇二, 他：幽門輪温存 膵頭十二指腸切除術を施行した超高齢者の十二 指腸乳頭部癌の 1 例. 日外科系連会誌 $36: 641-$ 644, 2011

8）福島 亘, 小西孝司, 辻 雅彦, 他：80歳以上の 高齢者に対する膵頭十二指腸切除術の検討. 日消 外会誌 $26: 2416-2422,1993$

9）木下壽文, 中山和道, 杉山俊治, 他：膵頭部領域 に対する高齢者膵頭十二指腸切除術の検討．日臨 外会誌 $54: 350-355,1993$

10）杉本元一, 後藤田直人, 高橋進一郎 : 80歳以上の 高齢者に対する膵頭十二指腸切除術における術 後合併症からみた術前リスク評価と周術期介入 効果. 日外感染症会誌 9:293-298, 2012

11) Gordon TA, Burieyson GP, Tielsch JM, et al: The effects of regionalization on cost and outcome for one general high-risk surgical procedure. Ann Surg 221:43-49, 1995

12) Lieberman MD, Kilburn H, Lindsey $M$, et al: Relation of periperative deaths to hospital volume among patients undergoing pancreatic resection for malignancy. Ann Surg 222:638645, 1995

13) Nordback L, Parviainen M, Raty S, et al: Resection of the head of the pancreas in Finland: effects of hospital and surgeon on short-term and long-term results. Scand J Gastroenterol $37: 1454-1460,2002$

14）日本膵臓学会編：科学的根拠に基づく膵癌診療ガ イドライン 2009年版. 膵癌診療ガイドライン改 
訂委員会，金原出版，東京，2009，p122-124

15) Schmidt CM, Turrini O, Parikh P, et al: Effect of Hospital Volume, Surgeon Experience, and Surgeon Volume on Patient Outcomes After Pancreaticoduodenectomy: A Single-Institution
Experience. Arch Surg 145:634-640, 2010

16) Tseng JF, Pisters PWT, Lee JE, et al: The learning curve in pancreatic surgery. Surgery $141: 4456-463,2007$

\title{
Factors for Early Discharge After Pancreaticoduodenectomy in Patients Aged 80 Years and Older
}

\author{
Kiyoshi Kajiyama, Norifumi Harimoto, Shigeyuki Nagata, Yoshie Hirayama, \\ Tomoyuki Nakanoko, Takafumi Yukaya, Rintaro Yoshida, Kojiro Nishida, \\ Tadashi Koga and Masanori Kai \\ Department of Surgery, Iizuka Hospital
}

Purpose: We discuss about the factors for early discharge after pancreaticoduodenectomy (PD) in patents older than 80 years. Methods: 12 cases that underwent PD in which patients older than 80 years of age were retrospectively reviewed. The patients were divided into two groups; those who could be discharged within 30 days after PD and those discharged more than 30 days after PD. Results: There were no differences in age,gender,diagnosis, comorbidity, operative procedure, reconstruction method of remnant pancreas, method of the remnant main pancreatic duct, operative time, blood loss, delayed gastric emptying, surgical site infection, postoperative complications, enteral nutrition, postoperative hospital stay, hospital death. The participation of the experienced surgeon of PD is significantly more frequent and pancreatic fistula is significantly less in the patients who could be discharged within 30 days after PD. Conclusions: For early discharge of the patients over 80 years after PD, participation of experienced surgeon of PD and prevention of pancreatic fistula are important.

Key words: pancreaticoduodenectomy, elderly patients, over 80 years old, surgeon's experience, early discharge 